Portland State University

PDXScholar

7-31-1975

\title{
Biochemical Description of a Lava Tube Lake in Southeast Oregon
}

John Edward Palmer

Portland State University

Follow this and additional works at: https://pdxscholar.library.pdx.edu/open_access_etds

Part of the Biology Commons

Let us know how access to this document benefits you.

\section{Recommended Citation}

Palmer, John Edward, "Biochemical Description of a Lava Tube Lake in Southeast Oregon" (1975).

Dissertations and Theses. Paper 2602.

https://doi.org/10.15760/etd.2599

This Thesis is brought to you for free and open access. It has been accepted for inclusion in Dissertations and Theses by an authorized administrator of PDXScholar. Please contact us if we can make this document more accessible: pdxscholar@pdx.edu. 
AN ABSTRACT OP THE THESIS OF John Edward Palmer for the Master of Science in Biology presented July 31, 1975.

Title: Biochemical Description of a Lava Tube Iake in Southeast Oregon.

APPROVED BY MENBERS OF THE THESIS COMMITTEE:

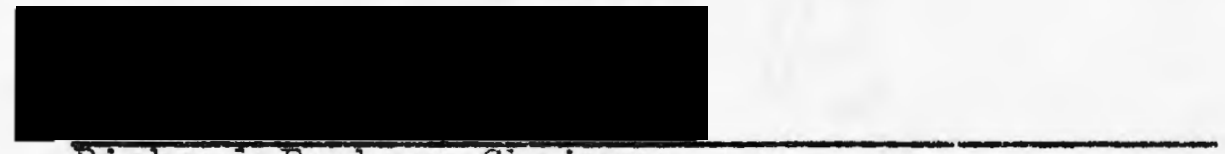

Richard Forbes, Crairman

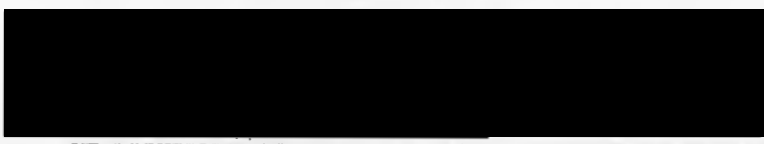

Richard Petersen

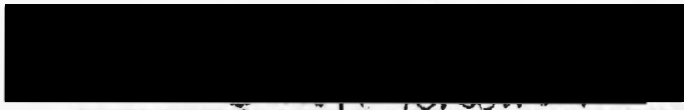

EarI Rosenwinkel

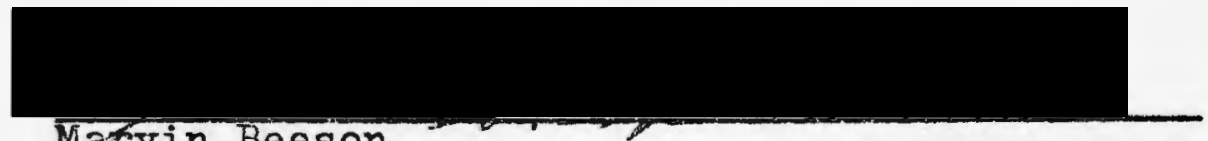

Mativin Beeson

A Pleistocene lava tube cave in southeast Oregon has a seasonaily fluctuating lake occupying the last 1200 to 2000 feet. Three endentionvertebrate species inhabit the lake: Kenkia rynchida Hyman; Asellus sp.; and Stygobromus hubbsi shoemaker. Littie is known however, about their environment.

The purpose of this study was to describe various physical and chemical parameters of Malheur Cave Lake. 
Parameters studied include: dissolved oxygen; $\mathrm{pH}$; total alkalinity; $\mathrm{Na}, \mathrm{K}, \mathrm{Ca}, \mathrm{Mg}, \mathrm{As}$ and $\mathrm{Hg}$ concentrations; water temperatures; water level fluctuations and turbidity; plankton content; and geothermometry. A food chain is hypothesized for the endemic invertebrate species. Data was collected monthly, excluding March 1975, from November 1974 through June 1975 at six stations on the lake. Malheur Cave lake has a low biological oxygen demand, is circumneutral in $\mathrm{pH}$, and low in ion concentrations. No thermocline exists, and the lake is homeothermic regardless of changing epigean ambient temperatures. Geothermal activity maintains homeothermy and a temporal constant water temperature of approximately $16^{\circ} \mathrm{C}$. The lake, with its three endemic invertebrate species, is essentially an island, with a high degree of stability. 
BIOCHEMICAL DESCRIPTION OF A IAVA TUBE LAKE

IN SOUTHEAST OREGON

$$
\text { by }
$$

JOHN EDWARD PAIMER

A thesis submitted in partial fulfillment of the requirements for the degree of

\author{
MASTER OF SCIENCE \\ in \\ BIOIOGY
}

Portland State University

1975 
TO THE OFFICE OF GRADUATE STUDIES AND RESEARCH:

The members of the Committee approve the thesis of

John Edward Palmer presented July 31, 1975.

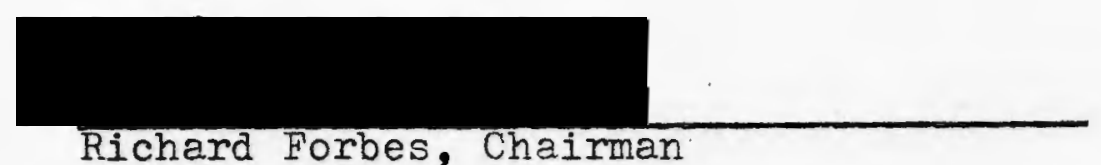

Richard Forbes, Chairman

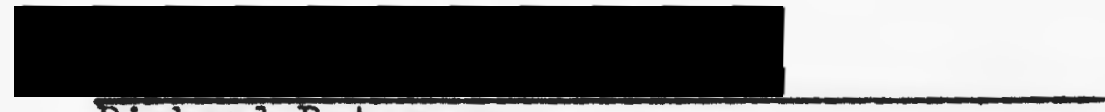

Richard Petersen

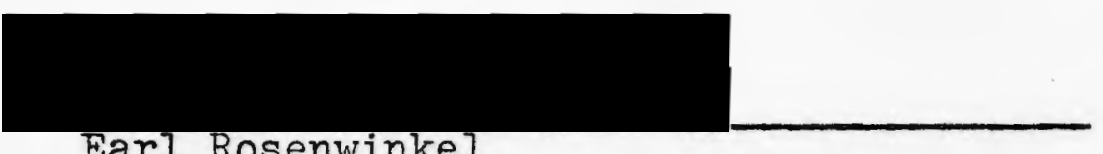

Earl Rosenwinkel

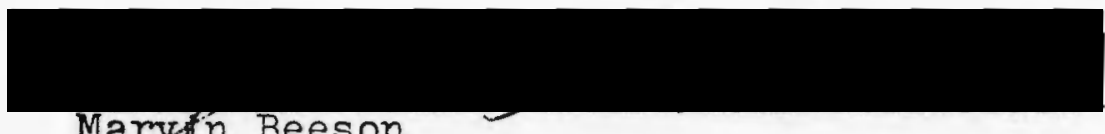

Maryin Beeson

APPROVED:

Earl Fisher, Head, Department of Biology

David Clark, Deen of Graduate Studies and Research

August 6, 1975 
I wish to thank Dr. Earl Fisher for the financial assistance for my Masters program. I thank Dr. Richard Forbes and the members of this committee for their help and advice. My appreciation is extended to those who aided in the collection of data, to Steve Knutson for giving his time in the mapping of Malheur Cave, to Charlie Larson for reducing and printing the maps, and to Ellen Benedict, whose help, advice and encouragement made this study possible. My deepest appreciation is extended to my wife, Becky, for her continuous help and support. 
TABLE OF CONTENTS

PAGE

ACKNOWLEDGEMENTS. . . . . . . . . . . .

IIST OF TABLES. . . . . . . . . . . . .

IIST OF FIGURES . . . . . . . . . . . .

vii

INTRODUCTION. . . . . . . . . . . . .

MATERIALS AND METHODS .............

RESULTS

I Dissolved oxygen. ...........

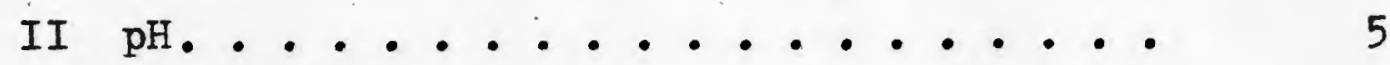

III Plankton analysis........... . . . 6

IV Total alkalinity. .......... 6

$\mathrm{V}$ Ion concentrations. ......... 6

VI Water temperatures.......... 7

VII Water levels and turbidity. ...... 7

VIII Geothermometry. ........... 8

DISCUSSION AND CONCLUSIONS. . . . . . . . . 9

BIBIIOGRAPHY. . . . . . . . . . . . 22

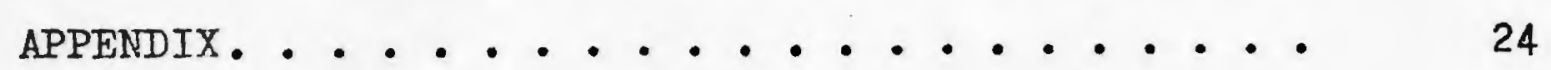

I Taxonomy of endemic

invertebrate species. . . . . . 
PAGE

II Map of Malheur Cave and vicinity. . . . . . . . . .

III Profile and planimetric map of Malheur Cave . . . . . . . 26 


\section{IIST OF TABLES}

TABIE

PAGE

I Dissolved oxygen levels

of Malheur Cave Iake ..........

II $\mathrm{pH}$ levels of Malheur

Cave Lake. . . . . . . . . . .

III Total alkalinity of

Malheur Cave Lake. . . . . . . .

IV Ion concentrations of MaIheur Cave Lake. . . . . . . .

$\checkmark$ Water temperatures of Malheur Cave Iake. . . . . . . .

VI Water levels and turbidity of Malheur Cave Lake . . . . . . .

VII Data for geothermometry. . . . . . . 
IIST OF FIGURES

FIGURE

PAGE

1 Graph of $\log K^{*}$ versus reciprocal

of absolute temperature.........

2 Map of Malheur Cave and vicinity ...............

3 Profile and planimetric map of Malheur Cave. . . . . . . . . . 


\section{INTRODUCTION}

Research in North American limestone and lava caves has centered on the faunal species exhibiting cave adaptation (Benedict and Malcolm, 1973; Hyman, 1937, 1945, 1956, 1960; Gurney, 1961; Kamp, 1963; Causey, 1960, 1972; Kenk, 1973), and several authors have reviewed information on cave-adapted organisms in the western United States (Crawford, 19́74; Holsinger, 1974; Peck, 1973). However, little research has focused on the chemical and physical parameters of North American lava tube caves.

Malheur Cave is a Pleistocene lava tube located in Harney County, Oregon (R. 36E., T. 27S., sec. 18) at an elevation of 4000 feet. The cave is approximately 3000 feet long, with a seasonally fluctuating lake occupying the last 1200 to 2000 feet. Malheur Cave is the only lava tube known to contain a lake. The lake harbors three endemic species of invertebrates: Kenkia rynchida Hyman, an aquatic troglobitic flatvorm; Asellus sp., an aquatic troglobitic isopod; and Stygobromus hubbsi Shoemaker, an aquatic troglobitic amphipod. Iittle is known, however, of the chemical and physical environment in which these three species live.

The object of this study was to ascertain and account for the following parameters of Malheur Cave Iake: the levels of dissolved oxygen, pH, alkalinity, and specific ions; 
water temperature; vertical water level fluctuations; turbidity; and estimated thermal reservoir temperatures. I also sought to hypothesize a food chain for the three endemic invertebrate species occupying the lake. Data acquired through this study would be useful to others investigating the lake and its inhabitants. 


\section{MATERIAIS AND METHODS}

In general, data on the lake were collected monthly, excluding March 1975, from November 1974 through June 1975. Six stations were designated on the lake at $200 \mathrm{ft}$ intervals by yellow tags placed on the North vall of the cave, with the first station $1800 \mathrm{ft}$ from the entrance. At each station, dissolved oxygen was recorded at 1.0 and 6.0 ft depths with a Yellow Springs Model 51A Dissolved Oxygen Meter, and pH was recorded with a Corming Nodel 6 Field pH Meter. Surface and bottom water samples were collected in polyetrylene cubitainers for ion analysis. No bottom water samples were obtained in April, May, or June. Weter turbidity was observed at the 2000 ft mark, utilizing a six-volt headlamp directed perpendicular to the water for illumination, and yellow tape placed on the dissolved oxygen probe at $1.0 \mathrm{ft}$ intervals. A water guage was placed at the $1760 \mathrm{ft}$ mark November 29 to measure vertical water rise. The water on this date ras the lovest observed during the study and was arbitrarily set at 0.00 . Benthos samples were collected in November and May with an Eckman Dredge for examination of plankton content. The dreage material was diluted to 1 liter with distilled vater, and two $100 \mathrm{ml}$ aliquots were filtered with 0.45 micron membrene filters (type HA Nillipore) and examined microscopically at $400 \mathrm{x}$. Two veter samples from 
November and May were selected at random, and two $100 \mathrm{ml}$ aliquots were filtered with 0.45 micron membrane filters (type HA Millipore) and examined microscopically at $400 \mathrm{x}$. Total alkalinity was determined by the Gran Plot method (Stumm and Morgan, 1970) with two water samples selected at random from each month of the study. Ryan thermographs, Model D-45WP, were placed on the bottom of the lake at 2200,2500 , and 2800 ft marks, and changed monthly to record temperatures for thirty-day periods. The water samples were analyzed for $\mathrm{Na}$, $\mathrm{K}, \mathrm{Ca}, \mathrm{Mg}$, As and $\mathrm{Hg}$ by Northwest Testing Laboratories, using a Perkin-Elmer Model $306 \mathrm{~b}$ atomic absorption spectrophotometer according to the manufacturer's instructions. To estimate the last temperature of water-rock interaction, and minimum thermal reservoir temperatures, the emperical method of Fournier and Truesdell (1973) was used. It is based upon molar $\mathrm{Na}, \mathrm{K}$, and $\mathrm{Ca}$ concentrations in natural waters from temperature environments ranging from 4 to $340^{\circ} \mathrm{C}$. One water sample was selected at random from each month of the study for geothermometry calculation (Table VII). 
RESUITS.

\section{DISSOLVED OXYGEN}

For the altitude and temperature of Malheur Cave Lake, $100 \%$ dissolved oxygen saturation is approximately $8.14 \mathrm{ppm}$, given by $S^{\prime}=S \times \frac{P}{760}$ for temperatures below $25^{\circ} \mathrm{C}$, where $S^{\prime}=$ solubility in $\mathrm{ppm}, \mathrm{S}=$ solubility at $760 \mathrm{~mm} \mathrm{Hg}$, and $\mathrm{P}=$ atmospheric pressure at time of sample collection (Iind, 1974). During the entire study, difficulty was encountered attempting to properly calibrate the dissolved oxygen meter. The meter failed to remain calibrated to the specific altitude of Malheur Cave. As a result, the meter was calibrated prior to each recording of dissolved oxygen. November data showed the lowest dissolved oxygen level, $7.4 \mathrm{ppm}$, followed by a substantial increase for the remainder of the study (Table I). The range for dissolved oxygen levels was 7.4 to $9.3 \mathrm{ppm}$, with no significant fluctuations between one and six-foot depth readings, or at different stations. With the exception of November, dissolved oxygen levels were above $100 \%$ saturation.

\section{II $\mathrm{pH}$}

The $\mathrm{pH}$ of Malheur Cave Iake ranged from 7.0 to 7.2 during December, with a subsequent rise occuring in January, 
April, and Nay (Table II). The highest $\mathrm{pH}$ level was recorded in May, with a subsequent drop in June. The lowest pH level recorded during the study was 7.0 , and the highest level 8.4 . No data on $\mathrm{pH}$ were obtained for November and February due to meter failure.

\section{PIANKTON ANALYSIS}

In both the two water samples and benthos samples, there was no evidence of plankton content. There appeared to be no fragments and/or complete skeletal components.

\section{TOTAI AIKAIINITY}

Total alkalinity values for Malheur Cave Iake ranged from $62 \mathrm{mg} / \mathrm{I} \mathrm{CaCO}_{3}$ to $78 \mathrm{mg} / \mathrm{I} \mathrm{CaCO}$ (Table III). There was no significant fluctuations between surface and bottom alkalinity values, or at the different stations.

\section{$\checkmark$ ION CONCENTRAPIONS}

The two trace elements tested from one acidified November water sample, $\mathrm{As}$ and $\mathrm{Hg}$, were near detection limits with values of $5.0 \mathrm{ppb}$ and less than $0.2 \mathrm{ppb}$ respectively. Concentrations for $\mathrm{Na}, \mathrm{K}, \mathrm{Ca}$, and $\mathrm{Mg}$ are given in Table IV. Sodium concentrations generally increased from January through May, decreasing in June. The range of $\mathrm{Na}$ concentrations during the study was from 39.5 to $47.6 \mathrm{ppm}$. Potassium concentrations showed a general increase in January which persisted 
throughout the study. The range of $\mathrm{K}$ concentrations during the study was from 2.6 to $3.6 \mathrm{ppm}$. Calcium concentrations showed no general increase during the study, with a range from 9.0 to $10.4 \mathrm{ppm}$. Magnesium concentrations showed a general increase from December through June, with a range from 2.2 to $3.1 \mathrm{ppm}$.

VI WATER TEMPERATURES

Surface and bottom temperatures recorded during the study varied a maximum of $1.1^{\circ} \mathrm{C}$. Slight decreases in temperature at both surface and bottom occurred from January through May (Table V). June surface temperatures showed a slight increase. During the study, maximum surface and bottom temperatures were 16.8 and $16.1^{\circ} \mathrm{C}$ respectively. Minimum surface and bottom temperatures were 16.0 and $15.0^{\circ} \mathrm{C}$ respectively. Maximum fluctuation for any one station and month was $0.8^{\circ} \mathrm{C}$.

VII WATER IEVEIS

AND TURBIDITY

December, January, and April water gauge data showed the largest influx of water into the lake (Table VI). February and May increases were slight. Data recorded May 14 and May 23 show the peak water level for the study. The water reached its highest level early in May, peaking at or near May 14, dropping slightly the latter part of May, and aropping significertly during June. Total vertical water 
rise observed was $3.0 \mathrm{ft}$, while the distance from the cave entrance to the lakeshore decreased a total of $725 \mathrm{ft}$, from $1750 \mathrm{ft}$ to $1025 \mathrm{ft}$ down-tube (Table VI).

In November, with a depth of $8.0 \mathrm{ft}$ at the $2000 \mathrm{ft}$ mark, the bottom was clearly visible (Table VI). From December through April, with depths from 8.65 to $10.70 \mathrm{ft}$, visibility was approximately $2.0 \mathrm{ft}$. From May 14 through June, with depths from 10.95 to $9.85 \mathrm{ft}$, the bottom was clearly visible again.

\section{ESTIMATED MINIMUM THERMAI RESERVOIR TEMPERATURES (GEOTHERMOMETRY)}

The temperature of Malheur Cave Lake was relatively constant during the study (Table $V$ ), and higher than regional mean ambient temperatures of approximately $8.0^{\circ} \mathrm{C}$ (Water Information center, 1974). The high, consistent temperatures suggest geothermal activity.

Data for most geothermal waters cluster near a straight Iine when plotted as the function $\log (\mathrm{Na} / \mathrm{K})+\beta \log (\sqrt{\mathrm{Ca}} / \mathrm{Na})$ versus reciprocal of absolute temperature, where $\beta$ is either $1 / 3$ or $4 / 3$ depending upon whether the water calibrates above or below $100^{\circ} \mathrm{C}$ (Foumier and Truesdell, 1973).

Data for Malheur Cave Lake (Table VII and Figure 1) calibrated below $100^{\circ} \mathrm{C}$, hence $\beta=4 / 3$. The estimated minimum thermal reservoir temperature was $75^{\circ} \mathrm{C}$. 


\section{DISCUSSION AND CONCLUSIONS}

The dissolved oxygen levels of Malheur Cave Lake indicate little demand is placed on the oxygen in the water by biological activity and/or waste material. The rise in dissolved oxygen levels coincides with the influx of water, but there appears to be no solid explanation to account for the increase. It is assumed that no significant fluctuations in atmospheric pressure occurred, the temperature of the lake is relatively constant, and reactions occurring in the surrounding rock would not account for the higher levels.

The pH changes in the lake coincide with water influx. The entire soil region of the cave is characterized as alkaline, and it is believed the surrounding basaltic rock contributes carbonate species to the lake, raising the $\mathrm{pH}$. The $\mathrm{pH}$ levels of the lake are not uncommon for waters in the area, and similar to tested regional geothermal springs (Mariner et. al., 1974).

The water levels of NaIheur Cave Lake vary seasonal.1y, with a lag period relative to regional precipitation. A specific water source for the lake would be unfeasible to hypothesize, since arid region groundwater exhibits a great deal of lateral movement, but it is believed that Malheur Cave intersects the groundwater table (Longwell, Flint, Sanders, 1969). A reservoir, constructed during the $1940^{\prime} \mathrm{s}$, is locat- 
ed approximately $1 / 4$ mile North of the cave, and could contribute water to the cave lake. . However, a water gauge placed in the reservoir showed no correlation between water levels in the cave and reservoir. Extensive ceiling drip is present above the lake portion of the cave, but would not account for the Iarge influx of water. The cave entrance does contribute a small amount of water to the lake through a small stream which, during February through April, did reach the lakeshore.

Water entering the lake appears to do so through the floor and/or walls beneath the water level. The presence of a geothermal reservoir at some depth beneath the tube offers support to this contention. During a period of rapid water influx into the cave lake, one would expect a cooling and equilibration of water temperatures. However, as the data illustrate, the temperature of the lake remains relatively constant. This can only be due to the presence of a geothermal source at some depth, and a characteristic movement of water to the lake. Water movement into the cave lake most likely follows a downward and/or lateral percolation to the geothermal source, upon which it is heated and subsequently moves upvard into the cave. This pattern of movement would account not only for the stable water temperatures, but also the observed turbidity, which results from bottom sediment disturbance.

In determining thermal reservoir temperatures, there are five basic assumptions which should be enumerated: 
(1) Temperature dependent reactions occur at depth; (2) There is an adequate supply of the constituents that are used as a basis for geothermometry; (3) Water-rock equilibrium occurs at reservoir temperature; (4) There is negligible re-equilibrium at lower temperatures as the water flows from the reservoir to the surface; (5) There is no dilution or mixing of the hot water coming from depth with shallow water. With the possible exception of (4) and (5), the basic assumptions probably apply to Malheur Cave. It is feasible, due to the temperature of the cave lake relative to the estimated thermal reservoir temperature, that dilution of the hot water and re-equilibration at lower temperatures occurs as the water flows from the reservoir to the surface. If indeed a dilution and re-equilibration is occurring between the thermal reservoir and cave lake, the estimated temperature for the geothermal reservoir of Malheur Cave lake $\left(75^{\circ} \mathrm{C}\right)$ would be much higher. If no dilution and/or re-equilibration occurs, the estimated geothermal reservoir temperature may be accurate, and the geothermal source may be "weak".

The concentrations of $\mathrm{Na}, \mathrm{K}, \mathrm{Ca}$, and $\mathrm{Mg}$ in the lake are low compared to regional geothermal springs, but possible contributing sources are limited due to non-exposure of the lake to the surface. Sodium is the principal cation, which correlates with tested regional geothermal springs (Mariner et. al., 1974). Arsenic and Mercury, often associated with geothermal waters, were found in minute concentrations in the lake. The amount of mixing that could occur between the geo- 
thermal source and the lake by other waters may contribute to the low values.

It is hypothesized that the three endemic invertebrate species occupying the lake have a detritus food chain. Reduced carbon sources could include: organic debris contributed through human activity, such as wood planks, garbage of various sorts; bacterial and fungal types, referred to as "cave slime" and "moon milk", present on the walis in the region of the lake; and dead invertebrate material. The invertebrates are probably low in population and metabolic activity, as is common with troglobitic species (Poulson and White, 1970), such that a large demand for nutrients may not exist. It appears that many of the parameters studiea coincide with and support data on the environment of endemic cave species, that is: the $\mathrm{pH}$ is at or above neutral, the temperature is relatively constant, and the water is "clean" or "good", referring to high dissolved oxygen levels. Such is the environment of Malheur Cave Iake.

In conclusion, Malheur Cave Lake has a low biological oxygen demand, is circumneutral in $\mathrm{pH}$, and low in ion concentrations. No thermocline exists, and the lake is homeothermic regardless of changing epigean ambient temperatures. Geothermal activity maintains homeothermy and a temporal constant water temperature. The lake, with its three endemic invertebrate species, is essentially an island, with a high degree of stability. 
TABIE I

DISSOLVED OXYGEN LEVELS OF

MAIHEUR CAVE IAAKE

\begin{tabular}{|c|c|c|c|c|c|c|c|c|}
\hline ATE & $\frac{\text { LAKE S? }}{\frac{1800}{1 ! 6 !}}$ & $\frac{\frac{10 N S}{2000}}{\frac{11}{6 !}}$ & $\frac{2200}{11}$ & $\frac{2400}{1^{1} 61}$ & $\frac{2600}{11 \frac{61}{11}}$ & $\frac{2800}{116}$ & .0 & $\%$ SAT \\
\hline 9 Nov & .47 .4 & 7.47 .4 & .67 .6 & .47 .4 & 7.47 .4 & 7.67 .6 & 7.46 & .64 \\
\hline $1 \mathrm{Dec}$ & $*$ & * & * & * & 1.19 .2 & .29 .3 & .20 & \\
\hline $1 \mathrm{~J}$ & .78 .7 & 8.68 .5 & 8.88 .8 & 8.78 .7 & 8.68 .7 & 8.68 .7 & 8.67 & \\
\hline $\mathrm{Fek}$ & 88.8 & 9.08 .8 & 8.88 .9 & $8.8 \quad 8.8$ & .88 .8 & 3.88 .8 & 8.82 & 10,0 \\
\hline $26 \mathrm{Apr}$ & 8.8 & 8.88 .8 & 8.88 .6 & 8.88 .7 & .88 .8 & $8.8 \quad 8.8$ & .77 & \\
\hline 3 May & & 8.88 .8 & 8.7. & 8786 & .6 & 8 & 8.74 & \\
\hline 3 & 78.6 & .68 .5 & 8.68 .6 & $8.6 \quad 8.7$ & .68 .5 & 8.58 .6 & 8.59 & 05.5 \\
\hline
\end{tabular}

* meter malfunction 
TABLE II

pH LEVEIS OF MAIHEUR CAVE IAKE

LAKE STATIONS 1800 2000 2200 $2400 \quad 2600 \quad 2800$

31 December

7.

7.1

7.0

7.1

7.2

7.2

31 January

$7.7 \quad 7.6$

7.4

7.7

7.5

7.6

26 April

8.0

8.0

8.0

8.0

8.0

7.6

23 May

8.4

8.4

8.2

8.2

8.2

8.2

14 June

$7.8 \quad 7.8$

7.9

7.8

7.9

7.8 


\section{TABIE III}

TOTAL ALKALINITY OF MALHEUR CAVE LAKE

29 November 2600'- surface

2800'- bottom

31 December 2000'- bottom

$2200^{\prime}$ - bottom

31 January 2600'- surface

2800' - bottom

22 February $1800^{\prime}$ - bottom

2200 - bottom

26 April

$2200^{\prime}$ - surface

$2600^{\prime}$ - surface

23 May

2200'- surface

$2800^{\prime}$ - surface

14 June

$2400^{\prime}$ - surface

$1800^{\prime}$ - surface
65.0

62.0

78.0

73.0

68.0

64.0

71.0

75.0

63.0

76.0

71.0

72.0

73.0

74.0 
TABLE IV

VARIOUS ION CONCENTRATIONS OF MALHEUR CAVE LAKE

\begin{tabular}{|c|c|c|c|c|c|}
\hline \multirow{2}{*}{ DATE } & \multirow[b]{2}{*}{ SAMPLE } & \multicolumn{4}{|c|}{ ION CONC. (ppm) } \\
\hline & & $\mathrm{Na}$ & $\overline{\mathrm{K}}$ & $\mathrm{Ca}$ & $\overline{M g}$ \\
\hline \multirow{12}{*}{29 November } & $1800-\mathrm{s}$ & 40.4 & 2.7 & 9.0 & 2.3 \\
\hline & $1800-b$ & 39.8 & 2.7 & 10.0 & 2.2 \\
\hline & $2000-s$ & 39.5 & 2.7 & 10.3 & 2.2 \\
\hline & $2000-b$ & 40.3 & 2.7 & 9.8 & 2.2 \\
\hline & $2200-s$ & 39.9 & 2.7 & 9.9 & 2.2 \\
\hline & $2200-b$ & 41.0 & 2.7 & 9.8 & 2.3 \\
\hline & $2400-s$ & 39.7 & 2.7 & 9.6 & 2.5 \\
\hline & $2400-b$ & 40.0 & 2.7 & 9.8 & 2.4 \\
\hline & $2600-s$ & 39.8 & 2.7 & 9.5 & 2.4 \\
\hline & $2600-b$ & 40.2 & 2.6 & 9.5 & 2.4 \\
\hline & $2800-\mathrm{s}$ & 39.8 & 2.7 & 9.6 & 2.3 \\
\hline & $2800-b$ & 40.3 & 2.7 & 9.4 & 2.4 \\
\hline \multirow{3}{*}{31 December } & $1800-\mathrm{s}$ & 42.3 & 2.7 & 10.0 & 2.4 \\
\hline & $2000-s$ & 42.3 & 2.7 & 10.0 & 2.6 \\
\hline & $2000-b$ & 42.5 & 2.7 & 10.1 & 2.6 \\
\hline
\end{tabular}

\begin{tabular}{|c|c|c|c|c|c|}
\hline \multirow[b]{2}{*}{ DATE } & \multirow[b]{2}{*}{ SAMPLE } & \multicolumn{4}{|c|}{ ION CONC. (ppm) } \\
\hline & & $\mathrm{Na}$ & $k$ & $\mathrm{Ca}$ & $\mathrm{Mg}$ \\
\hline \multirow{8}{*}{$\begin{array}{l}31 \text { December } \\
(\text { cont.) }\end{array}$} & $2200-s$ & 40.2 & 2.7 & 9.8 & 2.6 \\
\hline & $2200-b$ & 43.6 & 2.8 & 10.0 & 2.8 \\
\hline & $2400-s$ & 41.0 & 2.7 & 9.6 & 2.6 \\
\hline & $2400-b$ & 44.0 & 2.8 & 10.0 & 2.7 \\
\hline & $2600-s$ & 41.2 & 2.7 & 9.8 & 2.6 \\
\hline & $2600-b$ & 42.0 & 2.7 & 10.1 & 2.7 \\
\hline & $2800-s$ & 41.8 & 2.7 & 9.8 & 2.6 \\
\hline & $2800-b$ & 42.8 & 2.7 & 10.0 & 2.7 \\
\hline \multirow{7}{*}{31 January } & $1800-s$ & 45.0 & 2.9 & 9.6 & 2.8 \\
\hline & 2000-s & 45.0 & 3.0 & 9.7 & 2.8 \\
\hline & $2000-b$ & 46.6 & 3.0 & 9.7 & 2.9 \\
\hline & $2200-s$ & 43.8 & 2.9 & 9.5 & 2.6 \\
\hline & $2200-b$ & 47.1 & 3.2 & 10.1 & 3.1 \\
\hline & $2400-5$ & 44.0 & 3.0 & 9.2 & 2.7 \\
\hline & $2400-b$ & 47.6 & 3.2 & 9.7 & 3.1 \\
\hline
\end{tabular}


TABLE IV - CONTINUED

\begin{tabular}{|c|c|c|c|c|c|}
\hline \multirow[b]{2}{*}{ DATE } & \multirow[b]{2}{*}{ SAMPLE } & \multicolumn{4}{|c|}{ ION CONC. $(\mathrm{ppm})$} \\
\hline & & $\mathrm{Na}$ & $\mathrm{K}$ & $\mathrm{Ca}$ & $\mathrm{Mg}$ \\
\hline \multirow{4}{*}{$\begin{array}{l}31 \text { January } \\
\text { (cont.) }\end{array}$} & $2600-s$ & 42.5 & 2.8 & 9.5 & 2.6 \\
\hline & $2600-b$ & 47.0 & 3.6 & 10.3 & 3.1 \\
\hline & $2800-5$ & 45.3 & 3.0 & 9.5 & 2.9 \\
\hline & 2800-b & 46.5 & 3.4 & 9.6 & 3.1 \\
\hline \multirow{11}{*}{22 February } & $1800-5$ & 46.1 & 3.1 & 9.5 & 3.0 \\
\hline & $2000-8$ & 45.2 & 3.1 & 9.8 & 2.8 \\
\hline & $2000-b$ & 47.5 & 3.2 & 10.4 & 3.0 \\
\hline & $2200-s$ & 45.0 & 3.0 & 10.0 & 2.7 \\
\hline & $2200-b$ & 46.4 & 3.2 & 10.0 & 3.0 \\
\hline & $2400-s$ & 42.7 & 3.0 & 9.5 & 2.5 \\
\hline & $2400-b$ & 46.4 & 3.1 & 9.9 & 2.9 \\
\hline & $2600-s$ & 45.7 & 3.0 & 10.0 & 3.0 \\
\hline & $2600-b$ & 47.5 & 3.2 & 10.0 & 3.0 \\
\hline & $2800-s$ & 46.1 & 3.0 & 10,0 & 2.8 \\
\hline & $2800-b$ & 46.6 & 3.1 & 10.1 & 2.9 \\
\hline 26 April & $1800-s$ & 45.4 & 3.1 & 10.0 & 2.9 \\
\hline
\end{tabular}

\begin{tabular}{|c|c|c|c|c|c|}
\hline \multirow[b]{2}{*}{ DATE } & \multirow[b]{2}{*}{ SAMPLE } & \multicolumn{4}{|c|}{ ION CONC. (ppm) } \\
\hline & & $\mathrm{Na}$ & $\mathrm{K}$ & $\mathrm{Ca}$ & $\mathrm{Mg}$ \\
\hline \multirow{5}{*}{$\begin{array}{c}26 \text { Apr } 11 \\
\text { (cont.) }\end{array}$} & $2000-s$ & 45.6 & 3.1 & 10.0 & 2.8 \\
\hline & $2200-s$ & 44.8 & 3.1 & 10.0 & 2.7 \\
\hline & $2400-s$ & 46.0 & 3.1 & 10.0 & 3.0 \\
\hline & $2600-3$ & 45.6 & 3.0 & 10.1 & 2.9 \\
\hline & $2800-s$ & 45.7 & 3.1 & 10.1 & 2.9 \\
\hline \multirow{5}{*}{23 May } & $2000-9$ & 45.4 & 3.0 & 10.1 & 2.8 \\
\hline & $2200-3$ & 45.0 & 3.1 & 10.2 & 2.9 \\
\hline & $2400-s$ & 44.8 & 3.0 & 9.8 & 2.9 \\
\hline & $2600-8$ & 45.4 & 3.0 & 9.5 & 2.9 \\
\hline & 2800-s & 46.0 & 3.1 & 10.1 & 3.0 \\
\hline \multirow{6}{*}{14 June } & $1800-8$ & 43.5 & 3.0 & 9.7 & 2.7 \\
\hline & $2000-8$ & 43.6 & 3.0 & 9.5 & 2.8 \\
\hline & $2200-s$ & 43.3 & 3.0 & 9.6 & 2.7 \\
\hline & $2400-s$ & 43.0 & 3.0 & 9.8 & 2.6 \\
\hline & $2600-s$ & 42.8 & 3.0 & 9.8 & 2.5 \\
\hline & $2800-s$ & 43.8 & 3.0 & 9.9 & 2.7 \\
\hline
\end{tabular}




\section{TABIE V}

\section{WATER TEMPERATURES IN ${ }^{\circ} \mathrm{C}$}

OF MALHEUR CAVE IAAKE

\section{IAKE STATIONS}

$$
2200
$$

DATE

SURFACE BOTTO

SURFACE 80

\begin{tabular}{lllllll}
31 December & 16.8 & 16.1 & 16.8 & 16.0 & 16.8 & 16.1 \\
31 January & 16.0 & 15.2 & 16.0 & 15.1 & 16.0 & 16.0 \\
22 February & 16.0 & 15.0 & 16.0 & 15.1 & 16.0 & 16.0 \\
26 ApriI & 16.0 & 15.0 & 16.0 & 15.0 & 16.0 & 15.5 \\
23 May & 16.0 & 15.0 & 16.0 & 15.0 & 16.0 & 15.0 \\
14 June & 16.6 & 15.0 & 16.5 & 15.0 & 16.5 & 15.0 \\
\hline
\end{tabular}




\section{TABLE VI}

WATER IEVEI OF MAJHEUR CAVE IARE RELATIVE TO ZERO POINT ON GAUGE. AII DISTANCES NEASURED IN FEET

\begin{tabular}{|c|c|c|c|c|c|}
\hline DATE & $\begin{array}{l}\text { GAUGE } \\
\text { IEVEL }\end{array}$ & $\begin{array}{l}\text { IEVEI CH } \\
\text { REIATIVE TO } \\
\text { IAST IEVEI }\end{array}$ & $\begin{array}{l}\text { NGE } \\
\text { CUNU- } \\
\text { IATIVE }\end{array}$ & $\begin{array}{c}\text { DISTANCE TO } \\
\text { IAKESHORE }\end{array}$ & WATER \\
\hline 29 November & 0.60 & 0.00 & 0.00 & 1750 & clear \\
\hline 31 December & 1.25 & +0.65 & 0.65 & 1475 & turbid \\
\hline 31 January & 2.20 & +1.05 & 1.70 & 1300 & turbia \\
\hline 22 February & 2.45 & +0.25 & 1.95 & 1050 & turbid \\
\hline 26 April & 3.25 & +0.80 & 2.75 & 1030 & turbia \\
\hline 14 May & 3.50 & +0.25 & 3.00 & 1025 & clear \\
\hline $23 \mathrm{May}$ & 3.30 & -0.20 & 2.80 & 1035 & clear \\
\hline 14 June & 2.40 & -0.90 & 1.70 & 1060 & clear \\
\hline 28 June & 2.20 & -0.20 & 1.50 & 1300 & clear \\
\hline
\end{tabular}


TABIE VII

DATA FOR GEOTHERMOMETRY

IOG $\mathrm{K}^{*}=\operatorname{IOG}(\mathrm{Na} / \mathrm{K})+\beta \operatorname{LOG}(/ \mathrm{Ca} / \mathrm{Na})$

\begin{tabular}{|c|c|c|c|c|c|c|}
\hline MONMH & $\frac{\text { ION CONS }}{\mathrm{Na}}$ & $\frac{\text { (MOIA }}{\mathrm{K}}$ & $\frac{(I T Y)}{C a}$ & $I(\mathrm{Na} / \mathrm{K})$ & $I(/ \mathrm{Ca} / \mathrm{Na})$ & IOG $\mathrm{K}^{*}$ \\
\hline Nov. & .001732 & .000069 & .000295 & 1.39967 & .95995 & 2.67960 \\
\hline Dec. & .001818 & .000069 & .000295 & 1.42062 & .93892 & 2.67251 \\
\hline Jan. & .001849 & .000072 & .000237 & 1.40960 & .92044 & 2.63685 \\
\hline Feb. & .002067 & .000082 & .000249 & 1.40140 & .88315 & 2.57893 \\
\hline Apr. & .001949 & .000079 & .000249 & 1.39217 & .90870 & 2.60371 \\
\hline May & .001958 & .000079 & .000254 & 1.39140 & .91089 & 2.60860 \\
\hline June & .001906 & .000077 & .000247 & 1.39358 & .91619 & 2.61508 \\
\hline
\end{tabular}


21

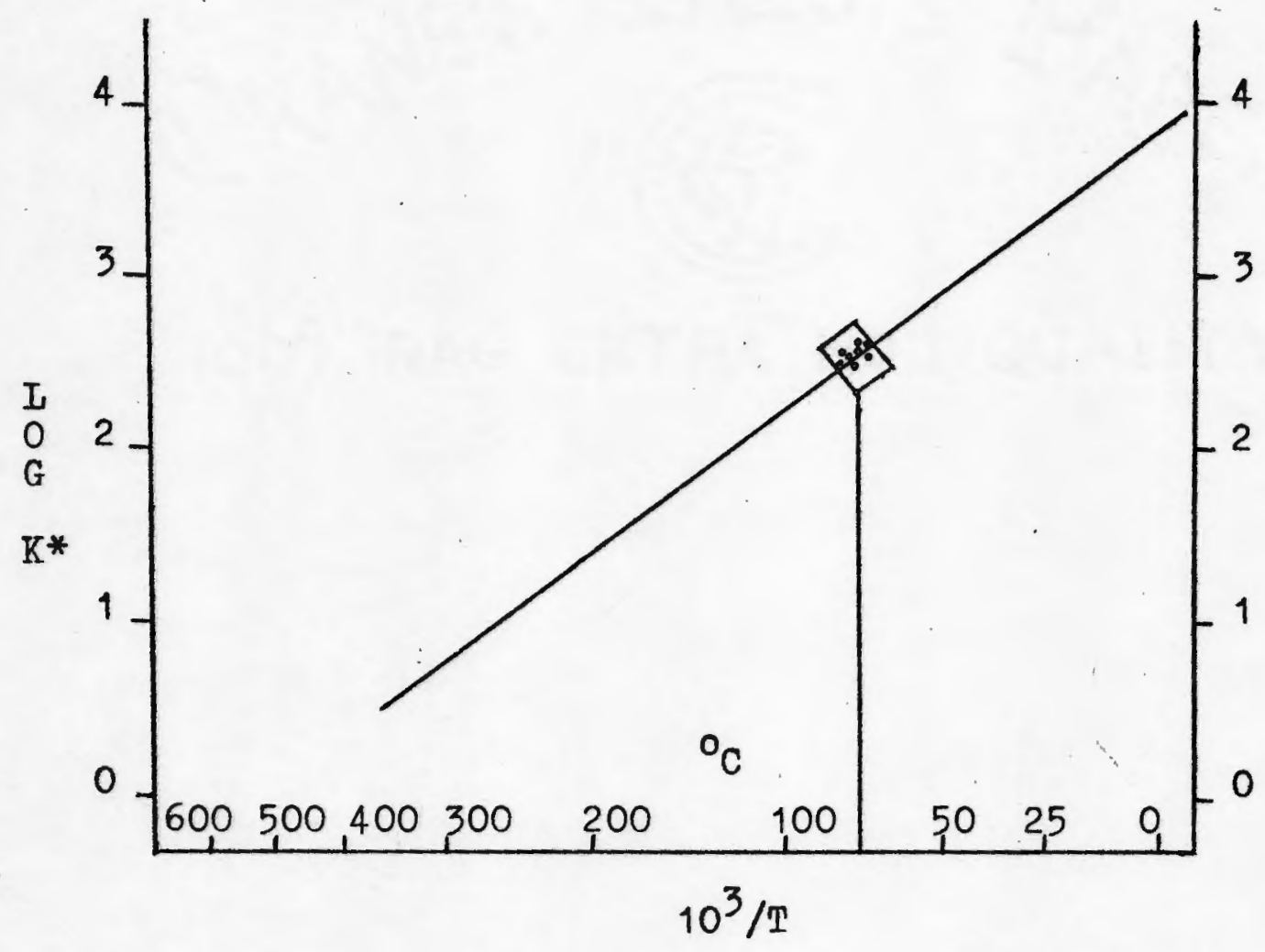

Figure 1. Graph of Log $K^{*}$ versus reciprocal of absolute temperature 


\section{BIBLIOGRAPHY}

Baldwin, Ewart M. (1964). Geology of Oregon. Edwards Brothers Inc., Ann Arbor, Michigan.

Benedict, E.M. and David R. Malcolm (1973). A new cavermicolous species of Apochthonius(Chelonethida: Chthoniidae) from the western United States vith special reference to troglobitic tendencies in the genus. Trans. Amer. Micros. Soc., 92(4): 620-628.

Causey, N.B. (1960). Speciation in North American cave millipedes. Am. Midl. Nat., 64(1): 116-122.

... (1972). Two new conotyloid millipedes from westerm North America and a key to the genus Adrityla(Chordeumida: Diplopoda). Proc. Louisiana Acad. Sci.., 35: 2732.

Crawford, R. (1974). Troglobites in the northwest. Northwest Caving, v.5(2-4).

Culver, D.C. (1970). Analysis of simple cave communities $I$. Caves as islands. Evolution, 24: 463-474.

Fournier, R.O. and A.H. Tmesdell (1973). An emperical NaK-Ca geothermometer for natural waters. Geochem. et Acta, $\nabla .37:$ 1255-1275.

Gurney, A.B. (1961). Further advances in the taxonomy and distribution of the Grylloblattidae(Orthoptera). Proc. Biol. Soc. Wash., 74: 67-76.

Hem, John D. (1970). Study and interpretation of the chemical characteristics of natural water. Geological Survey vater Supoly Paper, \#1473.

Holsinger, J.R. (1974). Systematics of the subterranean amphipod genus Stygobromus (Gammaridae), part I: Species of the westerm United States. Smithsonian Contributions to Z00logy, \#160

Hyman, I.H. (1937). Studies on North American triclad Turbellaria VIII. Some cave planarians of the United States. Trans. Am. Micros. Soc., 56: 457-477. 
(1945). Studies on North American triclad Turbellaria XI. New, chiefly cavernicolous, planarians, Am. Midl. Nat., 34: 475-484.

(1956). Studies on North American triclad Turbellaria 15. Three new species. Am. Mus. Novitates, 1808: 1-14.

(1960). Cave planarians in the United States. Am. Midl. Nat., 64: 10-11.

Kamp, J.W. (1963). Descriptions of two new species of Grylioblattidae and of the adult of Grylloblatta barberi, with an interpretation of their geographical distribution. Ann. Ent. Soc. Am., 56: 53-68.

Kenk, R. (1973). Freshwater triclads(Turbellaria) of North America, V: The genus Polycelis. Smith. Cont. Zool., $\# 135$.

Lind, Owen T. (1974). Handbook of Common Methods in Limnology. C.V. Mosby Company.

Iongwell, C.R., R. Flint, J. Sanders. (1969). Physical Geology. John Wiley \& Sons, Inc.

Mariner, R.H., J.B. Rapp, I.M. Willey, and T.S. Presser. (1974). The chemical composition and estimated minimum thermal reservoir temperatures of selected hot springs in Oregon. U.S. Dept. of Int.-Geol. Survey., Open-File Report.

Peck, S.B. (1973). A review of the invertebrate fauna of volcanic caves in western North America. Bull. of the Natl. Speol. Soc., 35(4): 99-107.

Poulson, T.I. and M. Smith. (1969). The basis for seasonal growth and reproduction in aquatic cave organisms. Actes IVe CIS., 4-5. - and W.B. White. (1970). The cave environment, Science.

Stumn, Verner and James J. Morgan. (1970). Aquatic Chemistry. John Wiley \& Sons, Inc.

Water Information Center, Inc. (1974). Climate of the States, v.II- Westerm United States. New York 
APPENDIX I

TAXONONY OF ENDEMIC INVERTEBRATE SPECIES

\section{PHYIUM: Platyhelminthes \\ CIASS : Turbellaria \\ ORDER : Tricladida \\ FAMILY: Planariidae}

Kenkia rynchida Hyman, 1937

This, the only species in the genus, is known only from the type locality, Malheur Cave, Hamey County, Oregon.

\section{PHYLUM: Arthropoda \\ CLASS : Crustacea \\ ORDER : Isopoda \\ FAMILY: Asellidae}

Asellus sp.

This species, as yet unidentified, collected from Malheur Cave, Harmey County, Oregon.

\section{PHYLUM: Arthropoda}

CIASS : Crustacea

ORDER : Amphipoda

FAMIIY: Gammaridae

Stygobromus hubbsi Shoemaker, 1942

The species is lnown only from the type locality, Malheur Cave, Harney County, Oregon. 